\title{
La creatividad de la enseñanza en la educación superior: una perspectiva comunitaria
}

\author{
Valérie Chanal $\left({ }^{*}\right)$

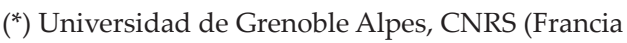

Valérie Chanal es profesora de Gestión de Innovación y Creatividad en la Universidad de Grenoble Alpes (Francia) y miembro de Cerag, laboratorio de investigación en ciencias de la gestión. Lidera el programa Promising dedicado al desarrollo y la difusión de nuevas pedagogías basadas en la creatividad, el diseño y la transdisciplinariedad.www.promising.fr

Dirección de contacto : Universidad Grenoble Alpes, CNRS, Grenoble INP*, CERAG, 38000 Grenoble, Francia. Valerie.Chanal@univ-grenoble-alpes.fr

\section{RESUMEN}

Hay una necesidad reconocida de transformar la educación superior para capacitar a los estudiantes «tipo T» que tienen competencias creativas y que cruzan fronteras. Presentamos aquí un programa realizado en la Universidad de Grenoble, Francia, dedicado al desarrollo de las competencias creativas. Se describen las dimensiones principales de la enseñanza de la creatividad. La enseñanza de la creatividad también va acompañada del aprendizaje mediante la práctica y de proyectos transdisciplinares. Luego mostramos cómo la introducción de la creatividad en la educación superior puede alcanzar el nivel institucional y ser un agente de cambio para los sistemas en su conjunto. Se basa en el desarrollo y la animación de una comunidad de prácticas que produce y comparte conocimientos sobre prácticas pedagógicas creativas. Uno de los efectos de esta comunidad es la apropiación por parte del gobierno del tema de la creatividad que conduce a decisiones estructurales en torno al espacio y el tiempo. Finalmente, tratamos los límites y las debilidades de este cambio de nivel de sistema.

Palabras Clave: creatividad, aprendizaje, enseñanza, innovación, Educación Superior.

\section{Introducción}

En la última década, la necesidad de innovación transformadora en la educación superior se ha acentuado (Christensen y Eyring, 2011; Leicester y Sharpe, 2018). Los altos índices de fracaso en los primeros años de universidad, las ideas de que los graduados no están adquiriendo los conocimientos adecuados, los recortes presupuestarios, las presiones para una mayor eficiencia debido a la masificación y a la transición digital son algunos de los aspectos de la gran transformación a la que se enfrentan las universidades en la actualidad. En este contexto de turbulencia, las universidades tienen el desafío de desarrollar competencias sociales y, más específicamente, competencias creativas (Capron-Puzzo, 2016).

Esta llamada para un cambio drástico, que actualmente es ampliamente reconocido en el sistema educativo, no es suficiente para que el cambio sea efectivo. La universidad es una antigua institución con reglas y prácticas establecidas durante siglos. La organización tradicional por departamentos disciplinares o la evaluación de la adquisición de conocimiento a través de exámenes finales son algunos de los aspectos de esta institución. Además, los profesores, los académicos y los administradores disponen de poco tiempo y recursos para introducir métodos in- novadores, porque su trabajo diario es muy exigente (Leicester y Sharpe, 2018). Hay muchos informes del futuro de la educación que promueven conceptos como «Competencias del siglo XXI» o «Estudiantes tipo T», pero raras veces se describe el proceso mismo de innovar para que emerja un nuevo sistema.

Con el fin de ofrecer algunas ideas de cómo podría ocurrir un cambio significativo en la práctica, en este artículo presentamos algunas lecciones sobre la introducción de la creatividad desde una amplia experimentación, que actualmente se está llevando a cabo en la Universidad de Grenoble Alpes (Francia). Este programa, llamado Promising, está dedicado al desarrollo de competencias creativas entre todos los estudiantes, independientemente de su disciplina. Empezó en el año 2013 con fondos del Ministerio de Educación Superior francés. Promising actúa como una plataforma que proporciona medios y recursos a los académicos comprometidos en una transformación de su pedagogía hacia el aprendizaje mediante la práctica y la creatividad, lo que podríamos llamar aprender inventando. El programa ha impulsado una variedad de experimentos que nos permiten extraer algunas ideas que se tratan en este artículo.

En la primera parte, presentamos los principios pedagógicos fundamentales en el núcleo de este proyecto, en relación con el contenido y el tipo de pedagogía implementado para desarrollar 
las competencias creativas. En la segunda parte, nos centramos en el proyecto Promising como un agente de cambio y describimos una palanca principal de la gestión del cambio a nivel institucional: el desarrollo de una comunidad de práctica de profesores. Cuando proporcionamos ejemplos de algunos cambios concretos en la práctica que han sido posibles gracias a estos proyecto y tratamos los límites principales que vemos a nivel institucional.

\section{$1^{\mathrm{a}}$ parte. El desarrollo de competencias creativas: ¿qué se debe enseñar y cómo?}

Muchos expertos y responsables de las políticas en educación actualmente convergen en el mismo diagnóstico: la educación superior debería evolucionar drásticamente para poder enfrentar nuevos retos en la sociedad (p. ej. Taddei, 2018). Las nuevas competencias que el sistema educativo tiene que desarrollar para la gente joven se han sintetizado en diferentes modelos, como el modelo $4 \mathrm{C}$ de competencias del siglo XXI, las cuatro $C$, que representan Creatividad, Comunicación, Pensamiento crítico y Cooperación (www.p21.org). En consonancia con el modelo de competencias del siglo XXI se encuentra la idea de que los estudiantes deberían convertirse en «personas tipo T». Esta noción sugiere que por encima del conocimiento disciplinar profundo en al menos una especialidad, (la barra vertical de la T), los estudiantes también deberían desarrollar una capacidad para funcionar como innovadores cruzando los límites entre especialidades con competencias transversales (la barra horizontal de la T) (Demirkan y Spohrer, 2015).

Estos modelos son bastante abstractos, según nuestra opinión y a nivel general, y requieren unas pautas concretas para implementarlos en un entorno de educación superior. Los principios fundamentales que hemos adoptado para guiar el cambio pedagógico se presentan a continuación. Empezamos preguntando qué significa para nosotros introducir la creatividad en la educación superior. Seguidamente, nos centramos en el modelo en forma de $\mathrm{T}$ y planteamos preguntas sobre cómo construir competencias creativas transversales.

\section{1. ¿Qué significa enseñar creatividad?}

La creatividad a menudo se presenta como una de las competencias principales para los jóvenes en nuestra sociedad. En un informe reciente del gobierno francés, el matemático y miembro del Parlamento, Cédric Villani, opina que la creatividad actualmente se tiene que considerar como una cualidad esencial que se debe desarrollar en un mundo en constante cambio. Esto implica para él un cambio drástico de todo el sistema educativo. Según él, centrarse solamente en las capacidades cognitivas ya no es una opción y los métodos educativos deben reorientarse hacia el desarrollo de la creatividad, el pensamiento crítico y la cooperación (Villani, 2018, p. 114).

La creatividad generalmente se define como un proceso que conduce a un resultado que es novedoso y útil (Lubart, 2001). «Ser creativo» no es una capacidad única y homogénea, atribuida a algunas personas y no a otras. Más bien, a nivel individual y micro, la creatividad es una combinación de diferentes habilidades cognitivas, como la identificación de problemas, la codificación selectiva, el pensamiento divergente o la flexibilidad mental (Lubart et al., 2015). También está vinculado con las dimensiones conativas, como la tolerancia a la ambigüedad, la apertura a nuevas experiencias, la toma de riesgos y la motivación, y a factores emocionales, incluidas las emociones positivas y el placer (Lubart et al., 2015). A nivel macro o de proceso, la creatividad abarca diferentes actividades: comprensión de problemas, generación de ideas y desarrollo de soluciones. Cada una de estas actividades articula el pensamiento divergente -o explora muchas opciones- $\mathrm{y}$ el pensamiento convergente -o evalúa y elige entre las opciones (Isaksen et al., 1994). Las personas pueden mostrar preferencias hacia una o más de estas actividades que contribuyen a un proceso creativo (Puccio, 1999). Por ejemplo, algunas personas pueden sentirse más cómodas con la búsqueda de datos para aclarar un problema, mientras que otras pueden estar más entusiasmadas con la generación de ideas. Sin embargo, ambos tipos de personas contribuyen a un proceso creativo.

La creatividad de la enseñanza recupera en nuestro sentido dos fenómenos. Primero, puede significar construir una secuencia de aprendizaje con técnicas creativas, para alcanzar un mejor proceso de aprendizaje requiriendo una inversión de estudiantes a nivel cognitivo, emocional y conativo. Por ejemplo, en una secuencia pedagógica sobre el ciclo del agua, un profesor podría invitar a los estudiantes a imaginar qué podría ocurrir si desapareciesen las nubes (Capron Puozzo, 2016, p. 20). En tal caso, los métodos creativos son un medio para alcanzar objetivos de aprendizaje en varios ámbitos de conocimiento.

La creatividad de la enseñanza también significa entrenar a los estudiantes para que comprendan y utilicen los principios creativos para su vida futura, ya sea profesional o personal. En tal caso, es importante que los estudiantes no solo participen en varios talleres de creatividad, sino que desarrollen metareflexividad en sus propias preferencias. Por ejemplo, el «Creative Profiler» $\mathbb{R}$, desarrollado por el equipo del profesor Todd Lubart, evalúa las microhabilidades, como el pensamiento divergente, el pensamiento convergente, la apertura o la tolerancia a la ambigüedad. Para el nivel macro, el FourSight $\AA$, desarrollado por el equipo del profesor Gerard Puccio, destaca las preferencias de una persona hacia las diferentes actividades de un proceso creativo. Estas herramientas, entre otras, pueden ser útiles para ayudar a los estudiantes a entender qué son los procesos de creatividad básicos y cómo pueden desarrollar sus habilidades y preferencias creativas en diversas situaciones. Estas dimensiones de la creatividad de la enseñanza se resumen en la figura 1.

\subsection{Modelo interdisciplinar: cómo construir competencias que cruzan fronteras}

El modelo en forma de T se basa en la suposición de que además de la experiencia vertical, los estudiantes tienen que desarrollar «competencias que cruzan fronteras» para poder actuar como innovadores y trabajar con personas de diferentes orígenes (Demirkan y Spohrer, 2015). Para convertirse en estudiantes «tipo T», los estudiantes deben estar expuestos a diferentes situaciones del proyecto donde puedan experimentar el trabajo en equipos transdisciplinares.

Cuando una escuela de ingeniería o una escuela de negocios organice un desafío de creatividad, reunirá a equipos de estudiantes que tengan más o menos la misma formación académica. Estos estudiantes normalmente están capacitados para analizar situaciones de forma cartesiana y para buscar la respuesta «correcta», y son también bastante intolerantes al fracaso. Desafortunadamente, estos antecedentes de capacitación son incompatibles con una mentalidad creativa y, de alguna manera, se tienen que deconstruir. La creación de equipos transdisciplinares permite reunir a estudiantes con diferentes formas de pensar y de resolver problemas. Lleva a los participantes a aclarar y debatir sus valores, a explicar su punto de vista sin dar demasiadas cosas por sentado. Es interesante reunir en grupos a estudiantes con experiencia en arte o en diseño. Eickmann et al. (2004) han 


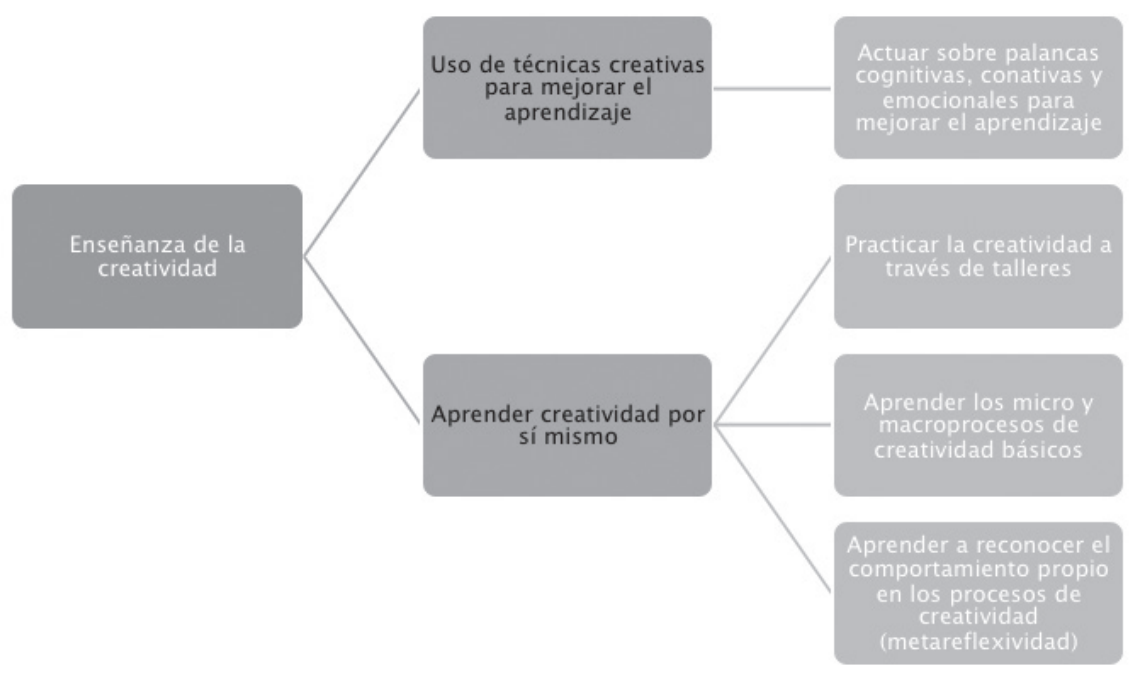

Figura 1. Dimensiones de la creatividad de la enseñanza y el aprendizaje

comparado la educación empresarial y el arte. Han identificado que la formación empresarial tiene tendencia a enfatizar la teoría, mientras que la educación en arte y diseño enfatiza la integración de la teoría y la práctica. Los estudiantes de arte y diseño están más orientados hacia la estética, la producción y la crítica, mientras que los estudiantes de empresariales están más orientados al aprendizaje científico y basado en textos. Reunir estos dos perfiles es una buena manera de equilibrar la imaginación y el análisis en los procesos creativos. También permite desarrollar habilidades de pensamiento sistémico, ya que los estudiantes aprenderán a abordar un problema complejo a través de diferentes lentes disciplinares. Además, los enfoques de creatividad promueven reglas de comportamiento, como escuchar a los demás, abrirse a la alteridad, posponer el juicio, que son especialmente útiles en los grupos transdisciplinares para ayudar a crear estas competencias que cruzan fronteras.

La transdisciplinariedad es un concepto distinto de la interdisciplinariedad. La interdisciplinariedad es una forma de hacer que diferentes ámbitos científicos trabajen juntos, pero al hacerlo, las fronteras de las disciplinas se evidencian y, por lo tanto, se refuerzan (Ingold, 2018). Más bien, la transdisciplinariedad trasciende el alcance de las disciplinas a través de una síntesis general (Thomson Klein, 2017). No es una tarea fácil hacer que los académicos piensen en términos de «transdisciplinariedad», ya que su identidad profesional se basa principalmente en su disciplina. Además, los planes de estudio disciplinares raramente ofrecen tiempo y espacio comunes para reunir a estudiantes de varios perfiles. Esto significa que las instituciones académicas tienen que establecer oportunidades de proyectos transversales y alentar a equipos transdisciplinares no tan solo de estudiantes, sino también de profesores, que también necesitan aprender a trabajar juntos y poder guiar los proyectos de los estudiantes en campos en los que no son expertos.

Aprender mediante la práctica es otro aspecto importante de la formación creativa. Primero, vemos el aprendizaje mediante la práctica como un aprendizaje experimental (Kolb, 1984), es decir, que los estudiantes trabajan en casos reales y, si es posible, en problemas que ellos mismos han escogido y que ofrecen la posibilidad de implementarse en la práctica. Este es un ingrediente clave para la motivación de los estudiantes y, por lo tanto, para el proceso de aprendizaje. El aprendizaje mediante la práctica y la transdisciplinariedad también significa que los estudiantes abordarán problemas en ámbitos con los que no están familiari- zados. A través de proyecto de creatividad aprenderán a buscar conocimiento relevante, a leer y comprender trabajos científicos, pero también a atraer su imaginación $\mathrm{y}$, finalmente, a elaborar propuestas originales. Esto contribuye a la formación de la barra horizontal en su perfil tipo $\mathrm{T}$.

Estas dimensiones de desarrollo de personas tipo $\mathrm{T}$ creativas se resume en la figura 2 .

Ahora que hemos visto algunos principios de pedagogía de la creatividad, pasamos a aspectos más organizativos para implementar dicho cambio en entornos académicos.

\section{Construcción de una comunidad de práctica y una organiza- ción pedagógica ampliable}

Como se ha propuesto anteriormente, la introducción de la creatividad en la educación supone un nivel de cambio que impacta en la totalidad del sistema académico. Las primeras personas involucradas son los miembros del profesorado, ya que tienen que volver a pensar su forma de enseñar y adoptar una nueva postura y mentalidad. Los proyectos de transdisciplinariedad también requieren una organización flexible de cursos que permitirá que los estudiantes participen en diferentes tipos de proyectos según sus intereses. Aquí presentamos e ilustramos estos dos niveles de gestión del cambio. El primero es la animación de una comunidad de prácticas de académicos involucrados en la creatividad. El segundo, describe las acciones llevadas a cabo a nivel universitario y los obstáculos que aún quedan.

\subsection{Desarrollo de una comunidad de prácticas}

Diferentes líneas de investigación y conceptos sobre gestión del conocimiento y la gestión del cambio han inspirado las acciones llevadas a cabo por el proyecto Promising desde 2014. Se basan más específicamente en tres nociones importantes: comunidades de prácticas, Ba y narración. Aquí nos basamos en el aprendizaje seminal de Wenger (1998), que presenta su teoría de comunidades de prácticas como una teoría social del aprendizaje (Chanal, 2000). De acuerdo con Wenger, los ingredientes principales para una comunidad de prácticas son un proyecto conjunto, un compromiso mutuo y un repertorio de conocimiento compartido. La práctica común tiene lugar en un espacio, teorizado por el trabajo de Nonaka y Konno (1998) bajo el concepto de «Ba». El «Ba» define un espacio para la construcción de cono- 


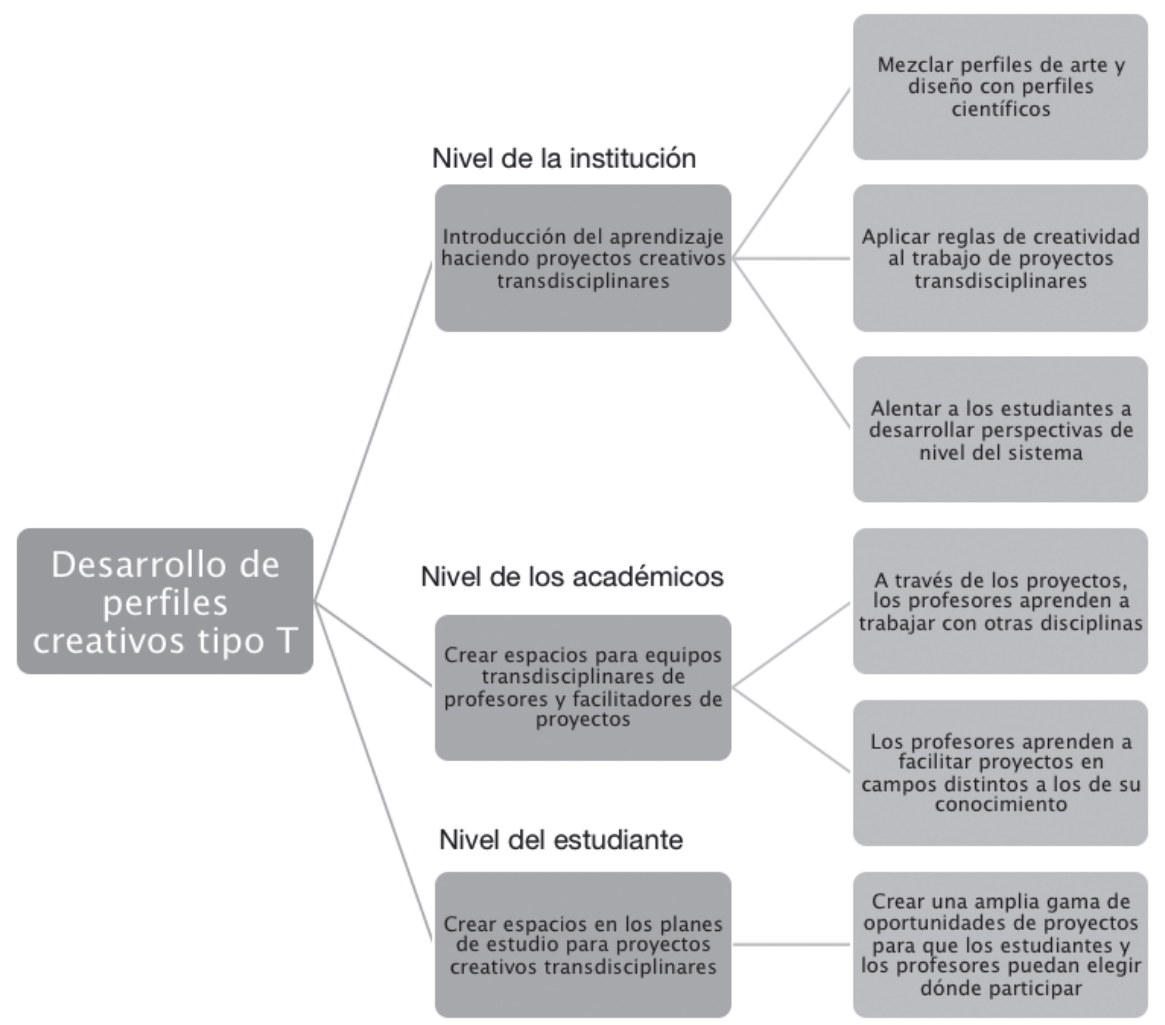

Figura 2. Dimensiones de desarrollo de perfiles tipo T creativos

cimiento común. Este espacio puede ser físico, virtual o mental (p. ej., práctica compartida). El relato es un medio para difundir el conocimiento producido por la comunidad a través de la institución. El relato se considera una palanca poderosa para fomentar la innovación y la gestión del cambio (Denning, 2001). Contar historias en lugar de presentar hechos y principios contribuye a dar sentido a lo que sucede en un período de cambio. Cuando se expone una historia a las personas, ellas hacen su propia interpretación y son capaces de construir sobre ella y adaptar el relato a su propio contexto. Esto es clave en un entorno organizado en silos disciplinares con sus propias reglas y prácticas y donde las personas pueden pensar que la creatividad no tiene nada que ver con su propia práctica. Estos principios se resumen en la figura 3.

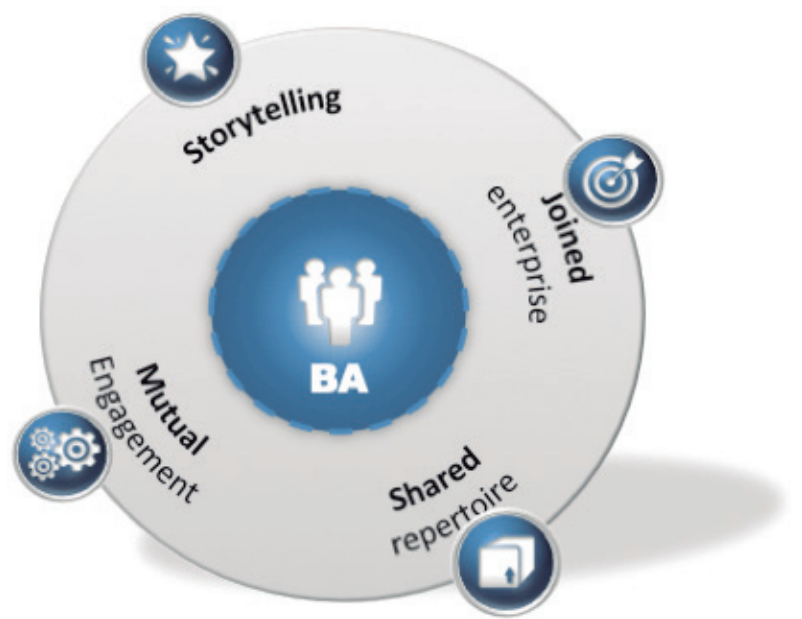

Figura 3. Una comunidad de prácticas como motor de creación de conocimiento

\section{Una historia del programa Promising}

En 2013, al comienzo del proyecto, una de las primeras acciones que se llevaron a cabo resultó ser un fracaso. El plan era proponer talleres de creatividad dentro de la oferta de cursos abiertos a la mayoría de los estudiantes de grado. Pensamos que los estudiantes apreciarían este formato, diferente de los cursos disciplinares tradicionales que se ofrecían. Aunque en ese momento el número de estudiantes potencialmente interesados era superior a 5.000, nos sorprendimos al ver que recibimos muy pocas inscripciones para inaugurar el curso. Tratamos de entender las razones y descubrimos que, de hecho, muchos estudiantes eligen sus cursos optativos siguiendo los consejos de sus profesores. Hasta cierto punto, están maximizando sus esfuerzos hacia lo que «es más rentable», en términos de reconocimiento académico. En ese momento, la creatividad no estaba tan «de moda» como ahora, y oímos comentarios bastante negativos como «esto no es serio» o «no estamos en la escuela primaria», etc. Entonces decidimos comenzar a inscribir a los profesores más motivados y abrimos un taller de creatividad para educadores. $Y$ tuvimos otra sorpresa: este primer taller de creatividad para profesores parecía ser muy popular y tuvimos que abrir otro para satisfacer la demanda. Así es como el programa comenzó a capacitar a académicos en la creatividad a un ritmo de unos 30 o 40 profesores nuevos anuales, para llegar, en 2019, a una comunidad de alrededor de 150 profesores capacitados en creatividad.

Actualmente, el programa Promising funciona como una plataforma de servicios que contribuye a la dinámica de creación de enseñanza de la creatividad basada en una comunidad de prácticas. En primer lugar, ofrece a los profesores una variedad de sesiones formativas sobre creatividad que no tan solo proporciona conocimientos y experiencia en creatividad, sino que también proporciona oportunidades para compartir experiencias peda- 


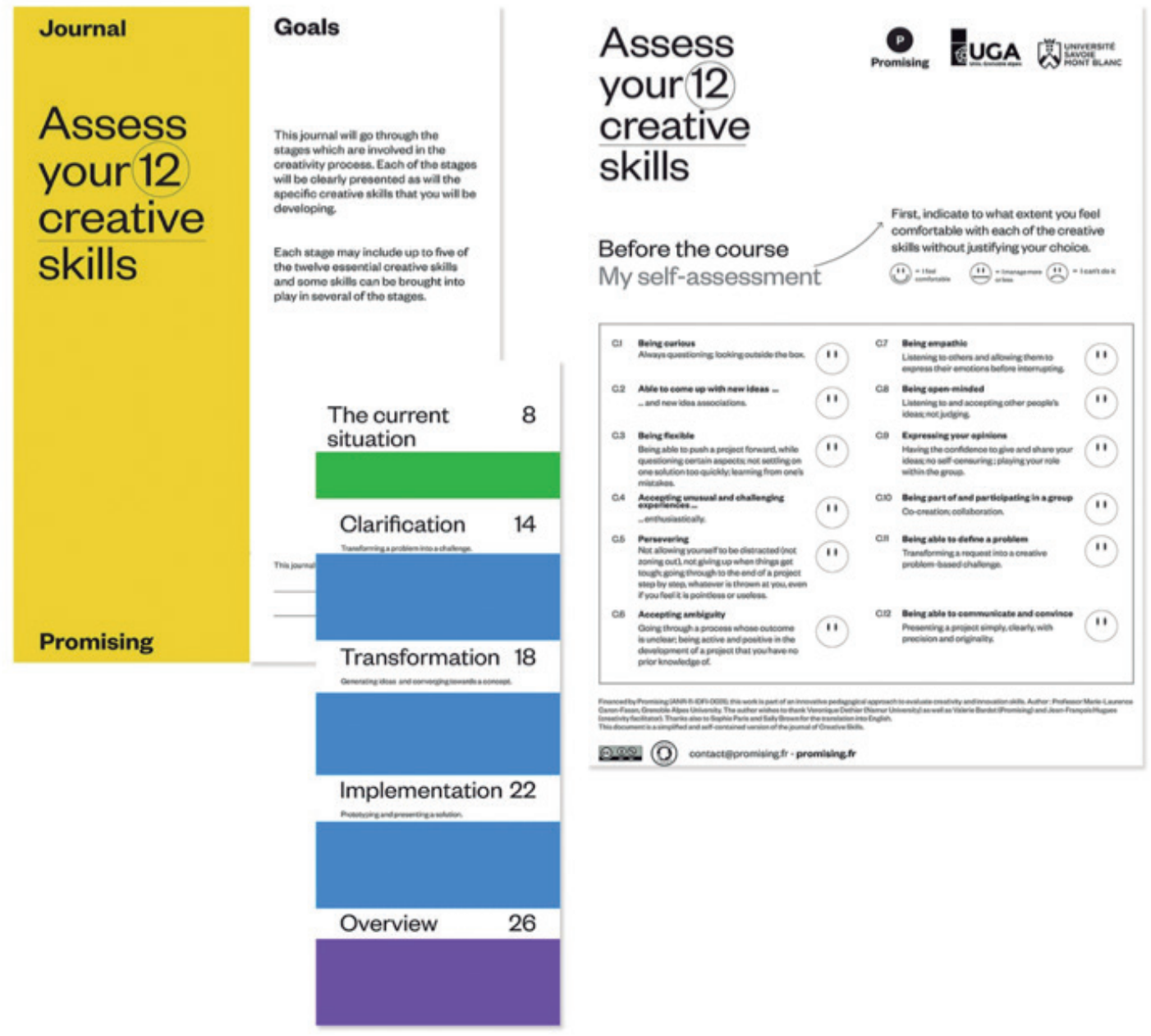

Figura 4. Resumen del diario de habilidades creativas desarrollado por la comunidad

gógicas. Los principios de la creatividad, como ser positivo hacia las ideas de los demás o el trabajo colaborativo para lograr un objetivo común, ahora son parte de la cultura comunitaria. Por ejemplo, un grupo de profesores una vez compartió la opinión de que no estaba satisfecho con los métodos de pensamiento divergentes $y$, por lo tanto, decidieron colaborar para crear los suyos propios y, un año más tarde, crearon una caja de herramientas que actualmente se edita y comercializa. En segundo lugar, el equipo de Promising trabaja en la capitalización del conocimiento escribiendo artículos, produciendo vídeos, organizando talleres o seminarios de conocimiento compartido, adoptando la regla de contar relatos. El conocimiento producido por la comunidad se introduce, así, en la capacitación. Por ejemplo, se ha desarrollado una revista para evaluar las habilidades creativas de los estudiantes (véase Caron y Bardot, 2018). Se ha desarrollado en francés e inglés y se puede descargar gratuitamente desde la página web de Promising. A continuación se presenta una descripción general de esta revista (Fig. 4).

Esta herramienta de evaluación presenta 12 habilidades principales, que se basan en investigaciones científicas sobre creatividad, pero que también han sido seleccionadas por los profesores como las más relevantes después de diferentes experimentos. Esta herramienta actualmente forma parte del repertorio compartido de la comunidad y la pueden seguir utilizando tanto profesores como estudiantes. La evolución del programa de capacitación en creatividad ilustra esta dinámica de creación de conocimiento: hace cinco años, el catálogo de capacitación se basaba principalmente en consultores externos. Actualmente, los miembros académicos de la comunidad proporcionan el $60 \%$ de las horas de capacitación (alrededor de 150 horas).

\subsection{Gestionar el cambio a nivel institucional}

El proceso continuo de capacitar a los académicos año tras año en una variedad de disciplinas alcanzó un punto donde el cambio se hace visible a nivel institucional y deja de ser un fenómeno marginal. El desarrollo de prácticas creativas bajo varias formas ha llevado a la gobernanza de la universidad a adoptar dos decisiones importantes. La primera ha sido asignar fondos a espacios pedagógicos adaptados a la creatividad. Hasta la fecha, se han equipado más de 30 aulas. La segunda decisión importante ha sido dedicar dos semanas en el curso académico, una en cada semestre, para permitir que los equipos pedagógicos organicen proyectos transdisciplinares. Estos son dos compromisos importantes de la presidencia de la universidad para apoyar la creatividad y el aprendizaje mediante el establecimiento de períodos de tiempo compartidos y el desarrollo de espacios adecuados. Sin embargo, las fragilidades persisten porque, debido a las limitaciones de planificación, muchos decanos de la facultad o líderes de programas no respetan esta planificación común y las cosas se tienen que renegociar a cada momento. Sin embargo, después de dos años, las iniciativas están creciendo en diferentes 
campos, como la administración, la arquitectura, ciencias políticas, salud o sociología, y están mostrando una dinámica positiva. Desde nuestro punto de vista, este es el dilema al que se enfrentan los programas transversales e innovadores: por un lado, el equipo de Promising está constantemente negociando espacios (físicos o temporales) para introducir la enseñanza de la creatividad en los planes de estudio. Por otro lado, también se convoca regularmente para organizar diferentes eventos creativos o para formar parte de asociaciones académicas con universidades internacionales. Esto se puede interpretar como un signo de un proceso lento de institucionalización, de abajo hacia arriba.

\section{Conclusión}

En este artículo presentamos los aspectos principales de la introducción de la enseñanza de la creatividad en una gran universidad multidisciplinar como respuesta a la necesidad de nuevas competencias de creatividad y a la capacitación de innovadores tipo T. Primero, se basa en una comprensión profunda de la creatividad que no se puede considerar como un aporte marginal en planes de estudio disciplinares como el azúcar al café. Por el contrario, enseñar creatividad significa centrar la atención en los procesos macro y micro, y llevar a los estudiantes a obtener una buena percepción de esos procesos mediante la práctica. También abarca posturas pedagógicas particulares, en particular el trabajo en equipo transdisciplinar y el aprendizaje experimental. La introducción de la creatividad en una universidad se tiene que considerar como un proceso de cambio real que involucra a la institución en su conjunto. Por lo tanto, requiere el apoyo de la gobernanza de la universidad para adoptar una organización que haga posible el desarrollo de la pedagogía basada en la creatividad a gran escala. Esto puede estar definiendo períodos comunes para organizar proyectos transdisciplinares, equipando aulas con muebles y materiales apropiados, y más generalmente introduciendo talleres basados en proyectos en todos los planes de estudio. Parece que este nivel de cambio se puede alcanzar con una lógica ascendente si un número suficiente de profesores ha experimentado estas prácticas y exige un cambio a un nivel más amplio. Por lo tanto, la asignación de medios con un equipo dedicado que puede apoyar y facilitar la creación de conocimiento sobre la creatividad dentro de una comunidad de prácticas es un ingrediente clave de la gestión del cambio. 


\title{
Teaching creativity in higher education: a community-based perspective
}

\author{
Valérie Chanal $\left(^{*}\right)$ \\ University of Oviedo (Spain) \\ $\left(^{*}\right)$ University of Grenoble Alpes, CNRS
}

Valérie Chanal is Professeur in Management of Innovation and Creativity at Grenoble Alpes University (France) and member of Cerag, laboratory of research in management sciences. She is leading the Promising program, dedicated to the development and diffusion of new pedagogy based on creati-

vity, design and transdisciplinarity. www.promising.fr

\begin{abstract}
There is a recognized need to transform higher education in order to train «T-shaped » students, having boundary-crossing and creative competencies. We present here a program carried out at Grenoble University, France, dedicated to the development of creativity competencies. The main dimensions of creativity teaching are described. Creativity teaching also goes along with learning by doing and transdisciplinary projects. We then show how the introduction of creativity in higher education can reach the institutional level and be a change agent for the system as a whole. It is based on the development and animation of a community of practice that produces and shares knowledge about creativity practices in pedagogy. One of the effects of this community is the appropriation by the governance of the creativity subject leading to structural decisions around space and time. Finally, we discuss the limits and fragilities of such a system level change.
\end{abstract}

Keywords: creativity, learning, teaching, innovation, Higher Education.

\section{Introduction}

In the last decade, the need for transformative innovation in higher education has been emphasized (Christensen and Eyring, 2011; Leicester and Sharpe, 2018). High levels of failure in the first years in university, ideas that graduates are not acquiring the right skills, budget cuts, pressures for more efficiency due to massification and the digital transition are some of the aspects of the major transformation that universities are facing today. In this context of turbulence, universities are challenged to develop soft skills and more specifically creativity competencies (CapronPuzzo, 2016).

This call for a drastic change, which is now largely recognized in the education system, is not sufficient for the change to be effective. University is an old institution with rules and practices established for centuries. The traditional organization by disciplinary departments or the evaluation of knowledge acquisition through final exams are some of the aspects of this institution. In addition, teachers, faculty and administrators have little time and resources to introduce innovation when their day job is so demanding (Leicester and Sharpe, 2018). If many reports on the future of education are promoting concepts such as "21th century competencies" or "T-Shaped students", the very process of innovating to make a new system emerge is rarely described.

In order to provide some insights on how some significant change could occur in practice, we present is this article some lessons on the introduction of creativity from a large experimentation currently carried on at Grenoble Alpes University (France). This program, named Promising, is dedicated to the development of creativity competencies among all students, whatever their discipline. It has started in 2013 with funding from the French Ministry of Higher Education. Promising acts as a platform providing means and resources to academics engaged in a transformation of their pedagogy towards learning by doing and creativity, what we could call learning by inventing. The program has stimulated a variety of experiments that enable us to draw some insights that are discussed in this article.

In the first part, we present the main pedagogical principles at the core of this project, concerning both the content and the type of pedagogy implemented to develop creativity competencies.

In the second part, we focus on the Promising project as a change agent by describing a main lever of change management at the institutional level: the development of a community of practice of teachers. We then provide examples of some concrete changes in practice that have been made possible thanks to this project and discuss the main limits we see at the institutional level.

\section{Part 1. Developing creativity competences: what should be taught and how?}

Many experts and policy makers in education now converge on the same diagnosis: higher education should evolve dramatically to be able to face new stakes in society (e.g. Taddei, 2018). The new competencies that the education system has to develop for young people have been synthetized in different models such as the $4 \mathrm{C}$ model of the $21^{\text {th }}$ century competencies, the four C's standing for Creativity, Communication, Critical thinking and Cooperation (www.p21.org). In line with the 21st century competencies model is the idea that students should become "T-shaped persons". This notion suggests that above deep disciplinary knowledge in at least one domain (the vertical 


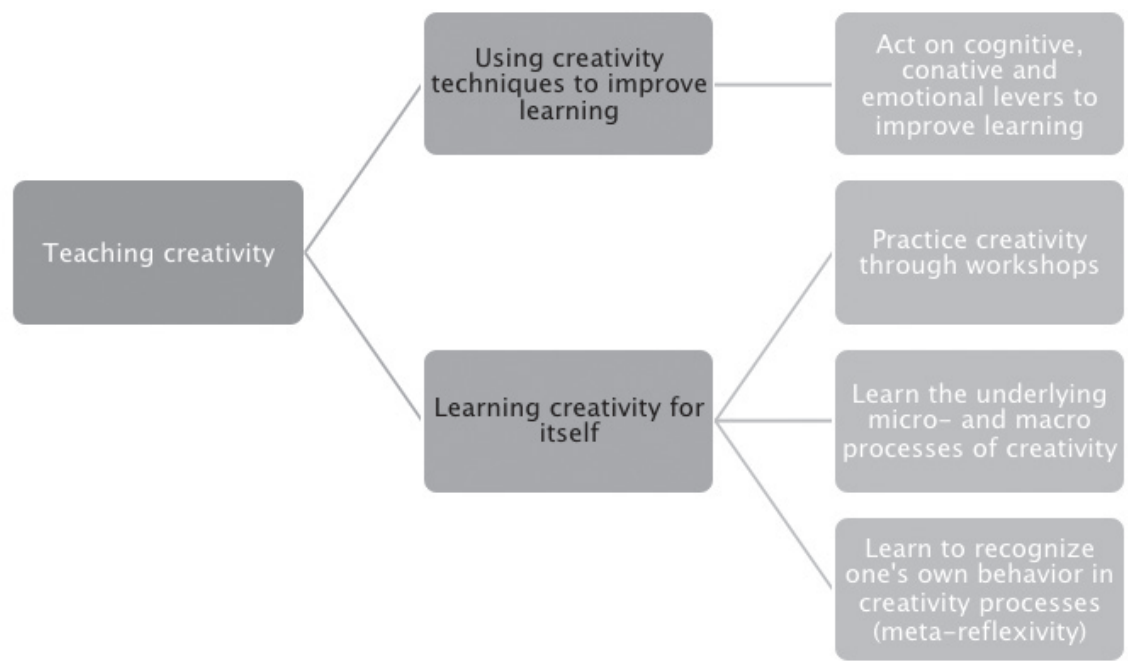

Figure 1. Dimensions of creativity teaching and learning

bar of the T), students should also develop an ability to function as innovators by crossing the boundaries between domains with transversal competencies (the horizontal bar of the T) (Demirkan and Spohrer, 2015).

These models remain in our view quite abstract and at a general level and require concrete guidelines to be implemented in a higher education environment.

The main principles that we have adopted to guide pedagogical change are presented below. We start by asking what it means to us to introduce creativity in higher education. We then focus on the T-Shaped model and raise questions on how to build transversal creative competencies.

\subsection{What does it mean to teach creativity?}

Creativity is often presented as one on the main competencies for young people in our society. In a recent report to the French Government, the mathematician and Member of Parliament Cedric Villani considers that creativity should now be considered has the essential quality to be developed in a perpetually changing world. This implies for him a drastic change of the entire educational system; according to him, focusing only on cognitive capabilities is not any more an option and teaching methods should be re-oriented towards developing creativity, critical thinking and cooperation (Villani, 2018, p. 114).

Creativity is usually defined as a process leading to an output that is both novel and useful (Lubart, 2001). "Being creative" is not a single and homogeneous capability, attributed to certain individuals and not to others. Rather, at a micro and individual level, creativity is a combination of different cognitive abilities like problem identification, selective encoding, divergent thinking or mental flexibility (Lubart et al., 2015). It is also linked to conative dimensions like tolerance to ambiguity, openness to new experiences, risk taking and motivation and to emotional factors including positive emotions and pleasure (Lubart et al., 2015). At a macro or process level, creativity covers different activities: problem understanding, idea generation and development of solutions. Each of these activities are articulating divergent thinking - or exploring many options - and convergent thinking - or evaluating and choosing among the options. (Isaksen et al., 1994). Individuals may express preferences towards one or more of these activities contributing to a creative process (Puccio, 1999). For example, some people may be more comfortable with data searching to clarify a problem while others may be more excited by ideas generation. Nevertheless, both types contribute to a creative process.

Teaching creativity recovers in our sense two phenomenon. First it can mean building a learning sequence with creativity techniques, to reach a better learning process by requiring an investment of students at the cognitive, emotional and conative levels. For example, in a pedagogical sequence on the water cycle, a teacher could invite students to imagine what would occur if clouds disappeared (Capron Puozzo, 2016, p. 20). In this case, creativity methods are a means to reach learning objectives in various domains of knowledge.

Teaching creativity can also mean training students to understand and use creativity principles for their future life, either professional or personal. In this case, it is important that students non only participate to various creativity workshops but also that they develop meta-reflexivity on their own preferences and attitudes towards the different activities of a creativity process. For example, the "Creative Profiler" ( ${ }^{\circledR}$ developed by the team of Pr. Todd Lubart, evaluates the micro abilities, like divergent thinking, convergent thinking, openness, or tolerance to ambiguity. For the macro level, FourSight ${ }^{\circledR}$ developed by the team of Pr. Gerard Puccio, highlights the preferences of an individual towards the different activities of a creative process. These tools, among others, may be useful to help students understanding what the underlying creativity processes are and how they can develop their creative skills and preferences in various situations.

These dimensions of teaching creativity are summarized in figure 1 .

\subsection{T-shaped model: how to build boundary-crossing competencies}

The T-shaped model is based on the assumption that on top of vertical expertise, students should develop "boundarycrossing competencies" to be able to act as innovators and work with people from different backgrounds (Demirkan and Spohrer, 2015). To become "T-shaped", students should then be exposed to different project situations where they can experiment working in transdisciplinary teams.

When an engineering school or a business school organizes a creativity challenge, it will bring together teams of students who have more or less the same academic background. These students are generally trained to analyze situations in a Cartesian 


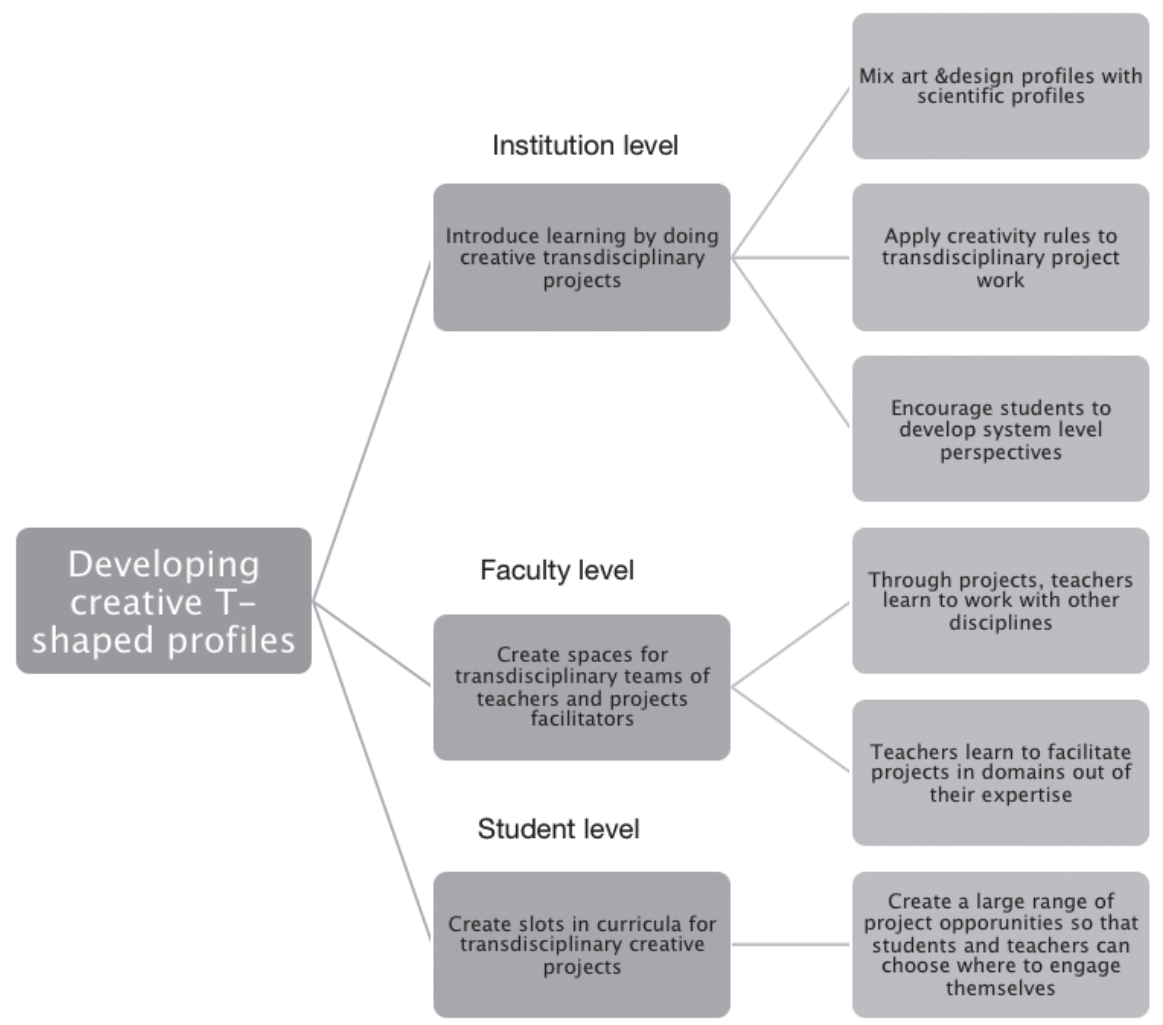

Figure 2. Dimensions of developing creative T-Shaped profiles

way and to look for the "right" answer, being also rather intolerant to failure. This training background is unfortunately incompatible with a creative mindset and has to be somehow de-constructed. Building transdisciplinary teams enables to put together students with different ways of thinking and solving problems. It leads participants to clarify and discuss their values, to explain their point of view without taking too many things for granted. It is interesting to bring into groups students with a background in art or design. Eickmann et al. (2004) have compared education in management and the arts. They have identified that management education tends to emphasize theory whereas art and design education emphasizes integration of theory and practice. Art and design students are more oriented towards aesthetic, production and critique, while management students are more oriented on scientific and text driven learning. Bringing those different profiles together are a good way to balance imagination and analysis in creativity processes. It also enables to develop system thinking skills due to the fact that students will learn to address a complex problem through different disciplinary lenses. In addition, creativity approaches promote rules of behavior like listening to others, being opened to otherness, deferring judgment, that are particularly useful in transdisciplinary groups to help creating these boundarycrossing competencies.

Transdisciplinarity is a concept distinct from interdisciplinarity. Interdisciplinarity is a way to make different scientific domains work together but by doing so the frontiers of disciplines are underlined and thus reinforced (Ingold, 2018). Rather, transdisciplinarity transcends the scope of disciplines through an overarching synthesis (Thomson Klein, 2017). It is not an easy task to lead academics to think in terms of "transdisciplinarity" because their professional identity is mainly based on their discipline. Moreover, the disciplinary curricula rarely offer common time and space to bring together students from various profiles. This means that academic institutions have to set up transversal projects opportunities and encourage transdisciplinary teams not only of students but also of teachers who also need to learn working together and be able to guide students' projects in domains they are not expert of.

Learning by doing is another important aspect of creativity training. First, we see learning by doing as experiential learning (Kolb, 1984), meaning that students work on real cases, and if possible, on problems they have chosen and that offer a possibility to be implemented in practice. This is a key ingredient to students' motivation and thus to the learning process. Learning by doing and trandisciplinarity also means students will address problems in domains they are not familiar with. Through the creativity project they will learn to seek relevant knowledge, read and understand scientific work but also to appeal to their imagination, and finally come up with original propositions. This contributes to the formation of the horizontal bar of their T-Shape profile.

These dimensions of developing creative T-shaped persons are summarized in figure 2.

Now that we have seen some principles of pedagogy of creativity, we turn to more organizational aspects, to implement such a change into academic environments.

\section{Building a community of practice and a scalable pedagogical organization}

As suggested above, the introduction of creativity in education implies a level of change that impacts the academic system as a whole. The first people concerned are the faculty members themselves, as they have to rethink their way to teach and adopt a new posture and mindset. Transdisciplinarity projects also require a flexible organization of courses that will allow students to participate to different types of projects, 
according to their interest. We present and illustrate here these two levels of change management. The first one is the animation of a community of practice of academics involved in creativity. The second one describes the actions undertaken at the university level and the obstacles that still remain.

\subsection{Developing a community of practice}

Different research streams and concepts in knowledge management and change management have inspired the actions undertaken by the Promising project, since 2014. They are more specifically based on three important notions: communities of practice, Ba and storytelling. We rely here on the seminal work of Wenger (1998), presenting his theory of communities of practice as a social theory of learning (Chanal, 2000). According to Wenger, the main ingredients of a community of practice are a joint enterprise, a mutual engagement and a shared repertoire of knowledge. The common practice takes place in a space, theorized by the work of Nonaka and Konno (1998) under the concept of "Ba". The "Ba" defines a space for the construction of common knowledge. This space can be physical, virtual, or mental (e.g. shared practice). Storytelling is a means to diffuse knowledge produced by the community through the institution. Storytelling is considered a powerful lever for fostering innovation and change management (Denning, 2001). Telling stories rather that presenting facts and principles contributes to giving meaning to what is happening in a change period. When exposed to a story, people will make their own interpretation and be able to build on it and adapt the narration to their own context. This is key in an environment organized into disciplinary silos with their own rules and practices and where people can think that creativity has nothing to do with their own practice. These principles are summarized in Figure 3.

\section{A story of the Promising program}

In 2013, at the very beginning of the project, one of the first action undertaken turned out to be a failure. The plan was to propose creativity workshops within the offer of open courses opened to a majority of undergraduate students. We thought that the students would appreciate this format, different from the traditional disciplinary courses offered. Although at this time, the number of students potentially concerned was over 5000, we had the surprise to see that we received too few

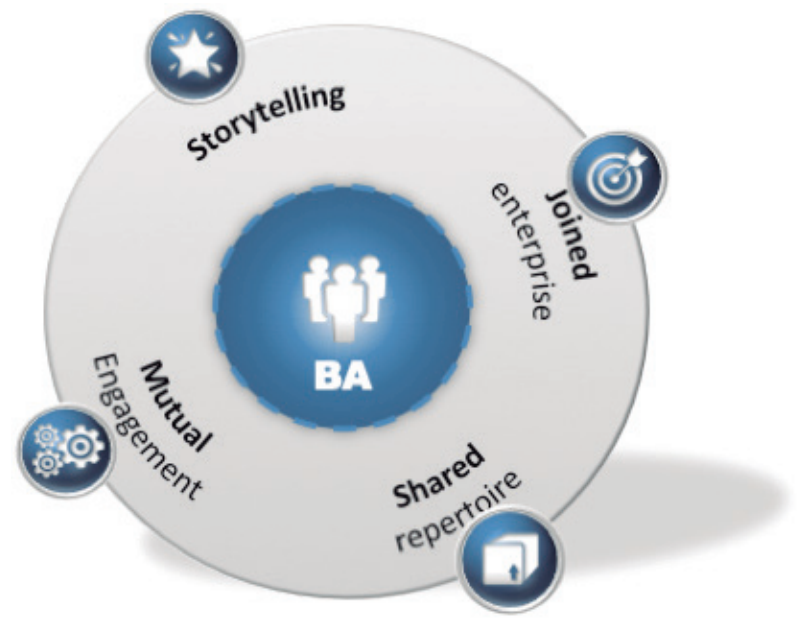

Figure 3. A community of practice as an engine of knowledge creation registrations to open the course. We tried to understand the reasons and discovered that in fact, many students choose their optional courses following the advice of their teachers. To a certain extent, they are maximizing their efforts towards what is "paying more" in terms of academic recognition. At this time, creativity was not so "fashion" as it may be today, and we heard quite negative commentaries like "this is not serious", or "we are not at primary school" etc. We decided then to start enrolling the most motivated teachers and opened a creativity workshop for educators. We had then another surprise: this first workshop in creativity for teachers appeared to be very popular and we had to open a second one to fulfil the demand. This his how the program began to train academics to creativity at a rhythm of about 30 to 40 new teachers a year, to reach, in 2019, a community of around 150 teachers trained in creativity.

Now the Promising program works as a platform of services contributing to the dynamics of knowledge creation on creativity teaching based on a community of practice. Firstly, it offers to teachers a variety of training sessions on creativity that does not only provide knowledge and knowhow on creativity but also gives opportunities to share pedagogical experiences. The principles of creativity like being positive to others' ideas or work collaboratively towards a common goal, are now part of the community culture. For example, a group of teachers once shared the view that they were not satisfied with diverging thinking methods and thus decided to collaborate to create their own, coming up after one year with a toolbox that is now edited and commercialized. Secondly, the Promising team works on knowledge capitalization by writing articles, producing videos, organizing sharing knowledge workshops or seminars, adopting the rule of storytelling. The knowledge produced by the community is thus continuously injected in training. For instance, a journal to assess students' creative skills has been developed (see Caron and Bardot, 2018). It has been developed in French and English and can be downloaded freely from the Promising website. An overview of this journal is presented below (Fig. 4).

This assessment tool presents 12 mains skills that are based on scientific research on creativity but also that have been selected by the teachers as the most relevant after different experimentations. This tool is now part of the shared repertoire of the community and can be used further by teachers and students. The evolution of the training program in creativity illustrates this knowledge creation dynamic: five years ago, the training catalogue relied mainly on external consultants; Today, the academics members of the community provide $60 \%$ of the training hours (around 150 hours).

\subsection{Managing change as the institutional level}

The ongoing process of training academics year after year in a variety of disciplines reached a point where the change becomes visible at the institutional level and is no longer a marginal phenomenon. The development of creativity practices under various forms has led the governance of the university to adopt two main decisions. The first one has been to allocate funds to pedagogical spaces adapted to creativity. At the present date, more than 30 classrooms have been equipped. The second important decision has been to dedicate two weeks in the academic year, one in each semester, to allow pedagogical teams to organize transdisciplinary projects. These are two important commitments of the University presidency to support creativity and learning by doing through the setting of shared time periods and the development of adequate spaces. Fragilities remain 


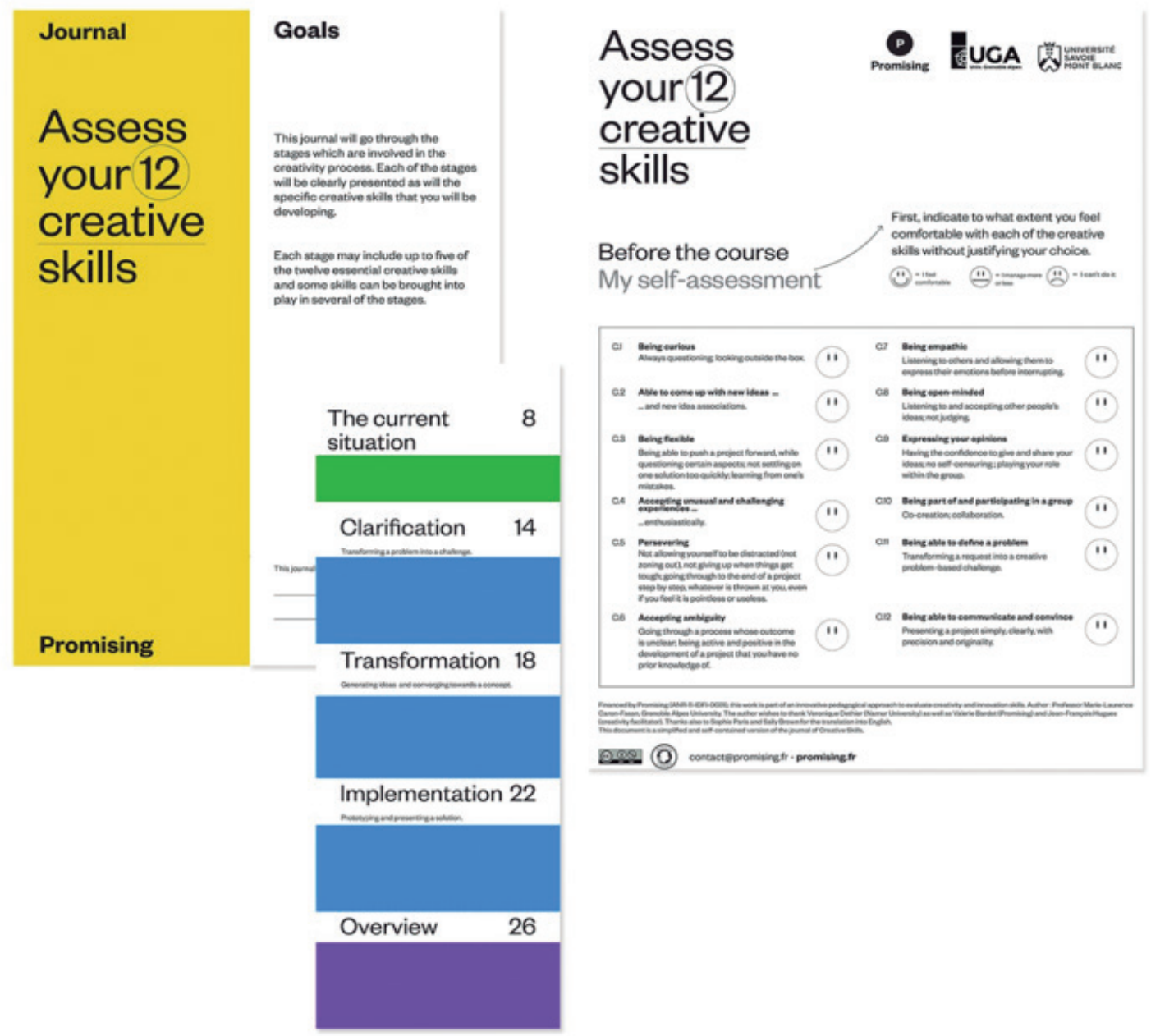

Figure 4. Overview of the journal of creative skills developed by the community

however, because due to planning constraints, many faculty deans or program leaders do not respect this common planning and things have to be re-negotiated at each time. Nevertheless, after two years, initiatives are growing in different fields like management, architecture, political sciences, health or sociology and are showing a positive dynamic. This is in our view the dilemma that such innovative and transversal programs are facing: on one side, the Promising team is constantly negotiating spaces (physical or temporal) to introduce creativity teaching in curricula. On the other side it is also regularly called on to organize different creative events or to be part on academic partnerships with international universities. This may be interpreted as a sign of a slow process of institutionalization, from the bottom-up.

\section{Conclusion}

In this article we have presented the main aspects of the introduction of creativity teaching in a large multidisciplinary university as an answer to the need of new creativity competencies and the training of T-Shaped innovators. It relies first on a deep understanding of creativity that cannot be considered as a marginal input in disciplinary curricula like sugar in the coffee. Rather, teaching creativity means focusing attention on both micro and macro processes and leading students to gain a fine perception of those processes through practice. It also embraces particular pedagogical postures, in particular transdisciplinary team work and experiential learning. The introduction of creativity in a university should also be considered as a real change process engaging the institution as a whole. It requires therefore support from the university governance to adopt an organization that rends the development of creativity-based pedagogy possible on a large scale. This may be defining common periods to organize transdisciplinary projects, equipping the classrooms with appropriate furniture and material, and more generally introducing project-based workshops in all curricula. It appears that this level of change can be reached with a bottomup logic if a sufficient number of teachers have experienced those practices and call for a change at a larger level. Therefore, the allocation of means with a dedicated team that can support and facilitate knowledge creation on creativity within a community of practice is a key ingredient of change management.

\section{Referencias / References}

Eickmann P., Kolb A. and Kolb B. (2004). Designing Learning, in: Managing as Designing, Boland R. and Collopy eds., Stanford Business Books, p. 241-247.

Capron Puozzo I. (ed) (2016). La Créativité en Education et Formation, Louvain la Neuve: De Boeck Supérieur.

Caron-Fasan M.L. et Bardot V. (2018). Comment évaluer les compétences creatives, The Conversation, https://theconversation. com/comment-evaluer-les-competences-creatives-89732 
Chanal V. (2000). Communauté de pratique et management par projet, RevueM@n@gement, vol.3,n¹

Christensen C.M. and Eyring H.J. (2011). The Innovative University. Changing the DNA of Higher Education from the Inside Out, San-Francisco, Jossey-Bass.

Denning S. (2001). The Springboard. How Storytelling Ignites Action in Knowledge-Era Organizations, Butterworth-Heinemann.

Demirkan H. and Spohrer J. (2015). T-Shaped Innovators: Identifying the Right Talent to Support Service Innovation, Research Technology Management, Sept. 1, p. 12-15.

Ingold T. (2018). L'Anthropologie comme Education, Presses Universitaires de Rennes

Isaksen, S.G., Dorval, K.B. and Treffinger, D.J. (1994). Creative Approaches to Problem Solving. Kendall.

Kolb, D. A. (1984). Experiential learning: Experience as the source of learning and development (Vol. 1). Englewood Cliffs, NJ: Prentice-Hall.

Leicester G. and Sharpe B. (2018). Transforming Higher Education. Who Will Create the Future?, Mac Graw Hill Education.
Lubart T. (2001). Models of the Creative Process: Past, Present and Future, Creativity Research Journal, 13:3-4, 295-308

Lubart T., Mouchiroud C., Tordjman S. and Zenasni F. ( 2015). Psychologie de la créativité, 2ième édition, Paris: Armand Colin.

Nonaka, I. and Konno, N. (1998). The concept of 'ba': building a foundation for knowledge creation, California Management Review, Vol. 40, pp. 40-54.

Puccio G. (1999). Creative Problem-Solving Preferences: Their Identification and implications, Creativity and Innovation Management, vol. 8, n³, p. 171-178.

Taddei F. (2018). Apprendre au 21ième siècle, Paris: Calmann Levy. Thomson Klein J. (2017). Typologies of Interdisciplinarity: The Boundary Work of Definition, in Frodeman Robert eds, The Oxford Handbook of Interdisciplinarity, Oxford University Press, p. 21-34.

Villani C. (2018). Donner un sens à l'intelligence artificielle, rapport parlementaire, https://www.aiforhumanity.fr/ pdfs/9782111457089_Rapport_Villani_accessible.pdf 